\title{
The Threat of Appendix CITES-Listed Turtles Harvesting in Central Borneo and South Sumatra
}

\author{
Muhammad Alif Fauzi ${ }^{1}$, Amir Hamidy ${ }^{2}$, Mumpuni ${ }^{2}$, Nia Kurniawan ${ }^{1 *}$ \\ ${ }^{1}$ Department of Biology, Faculty of Mathematics and Natural Sciences, Universitas Brawijaya, Malang 65145, Indonesia \\ ${ }^{2}$ Museum Zoologicum Bogoriense, Research Center for Biology - The Indonesian Institute of Sciences (LIPI), Bogor 16911, \\ Indonesia
}

Article history:

Submission April 2020

Revised June 2020

Accepted June 2020

*Corresponding author:

E-mail:

wawan@ub.ac.id

\begin{abstract}
Exploitation freshwater turtle for local consumption, medicine, and pet in several parts in Asia caused the declining populations in the wild. The purpose of this study is to evaluate of turtle harvest that listed in Appendix CITES in South Sumatra and Central Borneo. We reported the trading network of the three most exploited turtle species in South Sumatera and Central Borneo. We visited the largest middleman in the two provinces and collect the data that comprises the harvest number, prices, trade flow, catching area, and the level of harvest for local consumption. During our survey in Sampit (Central Borneo) (one week in April 2019), we recorded $667 \mathrm{~kg}$ of turtles were sent to a middleman and harvested from Jemaras and Sembuluh district. This amount comprises 549 individuals of Cuora amboinensis, 173 Siebenrockiella crassicollis, and one individual of Cyclemys dentata. Contrary to that, in Palembang, we did not find any delivery of turtle from the hunters. However, 387 individuals of $C$. amboinensis and 132 individuals of $S$. crassicollis were found in a middleman pool. We also recorded that local people in Central Borneo consumption of turtle meat. The national quota of C. amboinensis in Central Borneo and South Sumatra are 1700 and 2000 individuals for 2019. The national quota of $S$. crassicollis in South Sumatra is 500 individuals, while Central Borneo does not have any quota for this species. The realization of these wild-caught turtles indicates an over harvesting beyond the annual harvest quota. Moreover, the two middlemen are indicated to carry illegal carapace trading, although the scientific authority recommended to ban the carapace trade.
\end{abstract}

Keywords: Carapace, Harvest, Local Consumption, Quota

\section{Introduction}

The trade of wild animals is becoming a threat to the conservation of many species, especially in Southeast Asia [1]. Increasing of wildlife trade activities caused by several factors including, demand market, population growth, and economic aspects $[2,3,4,5]$. The abundance of wild animals in a developing country affects its economic growth $[4,6]$. It has been widely reported that the harvesting of wild animals is usually carried out by rural communities to fulfill their income $[5,7$, 8].

Every year that billions of dollars are obtained from the sales of wild animals and their derivative products $[4,7,9]$. Of the various traded animals, the reptile is the most traded animals that can be found in international pet market [10] after birds [11]. Among reptiles, the freshwater turtles and tortoises are the animals with the highest threat level $[10,12]$. The threatened of turtles in Asia is at a dangerous level. Over the past several decades, the utilization of turtles as food, medicine, and pet tend to affect the decline of the turtle population in China [13]. People in China believe that the consumption of turtle shells will give benefits to cure fever and cancer [14].

The declining of the turtle population in China makes this country needs to supply the de- 
mand market by importing turtles from other countries. Since early 2000, the turtles traded in China are imported from South Asia and Southeast Asia [10, 14, 15]. Indonesia has been the leading country that supplies hard-shell turtles for materials of traditional Chinese medicine in Taiwan [16]. A study explained that Indonesia is the leading supplier of Cuora amboinensis for consumption in Hong Kong and China [17]. The international of wildlife trade is regulated by the Convention on International Trade in Endangered Species of Flora and Fauna (CITES). The quota system is the regulation of the species listed in Appendix II. The trade of Appendix CITES-listed species must fulfill the aspects of sustainability, traceability, and legality. Although Indonesia has applied a quota system for wild harvest specimens, the illegal trade seems still occurs in some parts region. In this present study, we report the threatened, and the implementation of harvest quota system for Appendix CITES-listed turtles in Central Borneo and South Sumatera.

\section{Material and Methods}

This research was conducted in two different cities in Indonesia, Sampit (Central Borneo) and Palembang (South Sumatera). The survey in Sampit and Palembang was held on April 22-27 2019 and July $17-20^{\text {th }} 2019$ sequentially. In each city, we visited middlemen who have permits to sell the turtle at the national level (among the provinces) (based on the data of Management Authority (MA)). We counted the turtles bought by middleman from collectors and also conducted a semistructured interview with the middleman about the turtle network. The information collected was about buying and selling prices, the level of local consumption of turtles, the number of harvests, and also the location of hunting. The information about harvesting peak season, the harvest catching number, and the catching methods were collected through interviews with the hunters, which sell the turtles to the middleman. The conversion of turtle's prices here is shown in USD ( 1 USD= 14,140 IDR; October 20, 2019). All of the interview results are presented in a narrative descriptive.

\section{Results and Discussions Number of harvests}

The recorded data of turtle's supplies to a middleman in Sampit shows that 667 kilograms of tur- tles are sent from hunters in Jemaras and Sembuluh. This amount is the accumulation of harvest in one week. The turtles found in the middleman comprises 549 individuals of $C$. amboine sis (amboina box turtle), 173 individuals of Siebenrockiela crassicollis (Black marsh turtle) and also one individual of Cyclemys dentata (Asian leaf turtle). We also found a container of amboina turtles' eggs that are going to be hatchling efforts by the middleman. The proportion of $C$. amboinensis and $S$. crassicollis caught is $67.6 \%$ : $32.4 \%$.

The second city of turtle's survey was carried out at middleman in Palembang. During the survey, we found 387 individuals of C. amboinensis and 132 individuals of $S$. crassicollis. The total number turtles are recorded harvested from Ogan Komering Ilir District. The collectors in its area sent the turtle once in a month. In Palembang, the middleman has a poor recording system so, we could not get much information about turtle supply. The proportion of C. amboinensis and S. crassicollis recorded is $74 \%$ : $36 \%$. A research monitored the population of harvested turtles in North Sumatra and Jambi Province. C. amboinensis and $S$. crassicollis are caught with the proportion of $74.2 \%: 25.8 \%$ in the same habitat, which is an oil palm plantation area [18].

The high demand market for wildlife will give an impact on the decline of the wild population [19]. Amboina box turtles lay six eggs in one year [17] with probability hatchling success is $50 \%$. The reproduction ability of the black marsh turtle is much slower than amboina box turtles. Mature females lay three to four clutches, which each clutch is most often two eggs [20, 21]. Growth from juvenile to adult maturity of these two species takes $4.5-5$ years $[17,22]$. Looking at biological information such as the reproductive capacity and growth of these two species must be considered to the improvement of harvesting regulation.

The peak season of harvesting informed by the hunters coincides with the rainy season. Our finding of eggs during the survey in Sampit shows that Amboina box turtles lay eggs from December to April. The season for hatching eggs of the Amboina box turtle is from January to April [23, 24]. The breeding season of other species, C. mouhottii, is from May to July (rainy season) [25].

The nesting season of $S$. crassicollis is April to June [26]. During our survey, we found the female turtles harvest from wild, usually in preg- 


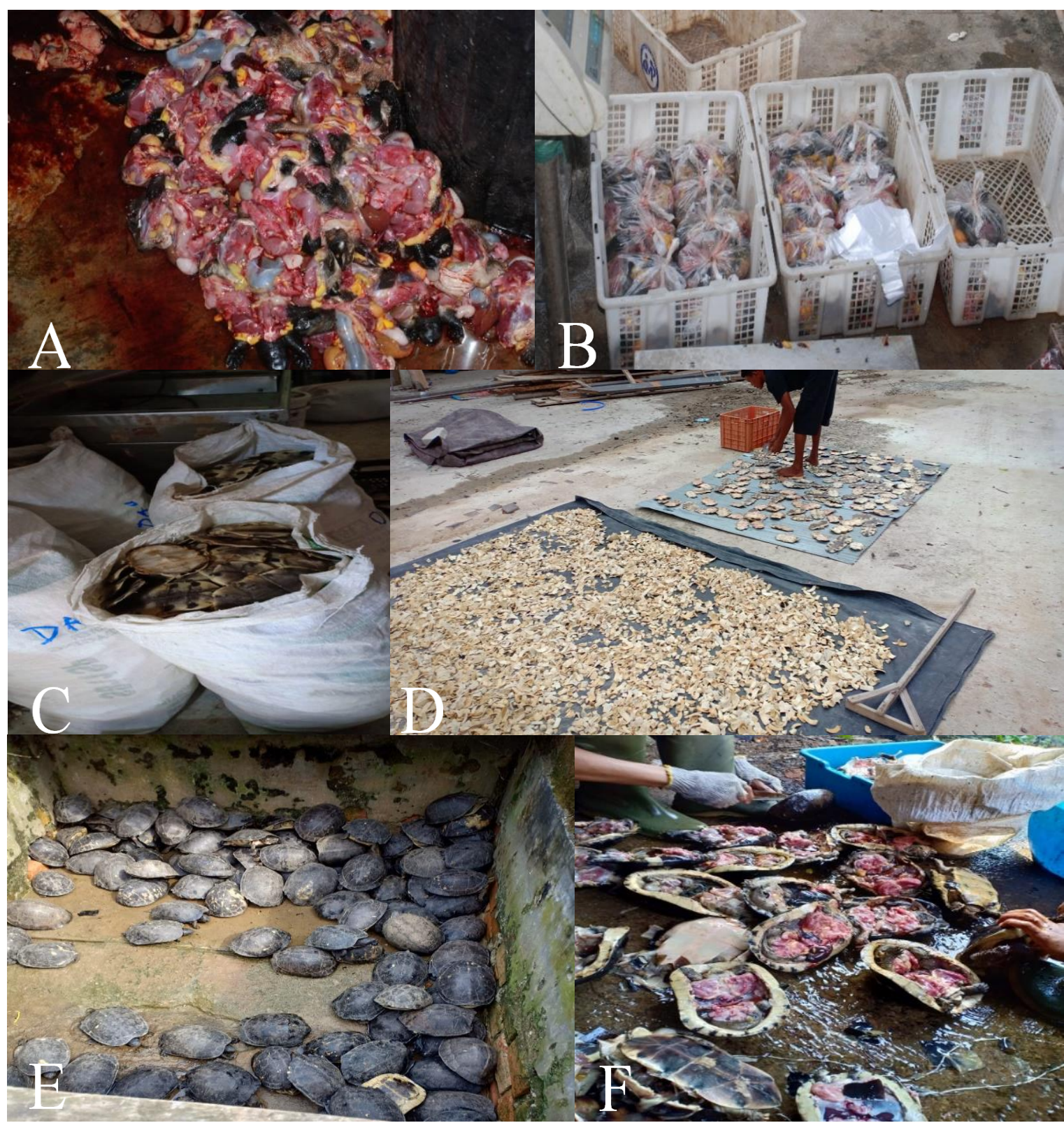

Figure 1. Turtle utilization A. The turtle meat for local consumption in Sampit, B. Packaging of turtles meat that ready to sell in local market , C. Packaging of plastron piles in the warehouse, D. Turtle shell dried in the sun, E. Pool for storing turtle in Palembang. F. Collection of carapace and plastron from the died turtle in Palembang (Photographs by Mumpuni and Hamidy)

nant stages and some eggs in sacks that bring by hunters. This condition is hazardous for the existence of these turtle in the wild population. Supporting this, Direktorat Konservasi Keanekaragaman Hayati (KKH - Directorate of Biodiversity Conservation) does not allow the harvesting of pregnant females. By considering the peak season and the regulation, we recommend to management authority for the socialization of limitations on the harvesting periods to avoid the preg- nant female being hunted. The restriction on the size harvest is also needed to anticipate the drastic population declining of both species in the wild.

\section{Domestic market}

We found the slaughtered live turtles and local consumption of turtle meat in middleman on Sampit (Figure 1A and B). The turtle meat from this slaughtering house is consumed by local people with a given price of USD 1.06/kg for the retailer 
or USD $1.41 / \mathrm{kg}$ for the ordinary buyer. This price corresponds to the Ministry of Environment and Forestry No. P86/MENLHK/SETJEN/KUM.1/11 $/ 2016$ about which set USD $1.06 / \mathrm{kg}$ as the standard price for $C$. amboinensis and $S$. crassicollis to sold in national and international levels. Interviews with five buyers from this middle-man reveal that the turtle meat is cheaper than chicken meat. [27] stated that the chicken meat price around $2.87 / \mathrm{kg}$. Thus, buyers tend to choose turtle meat as their protein sources. A research reported that people in rural areas consume meat from various wild animals such as mammals, birds, and reptiles for their protein content. The low-fat profile, calcium, iron, keratin and vitamin content in turtle meat also become another reason why turtle meat is in demand [29]

Besides the consumption of the meat, C. amboinensis and $S$. crassicollis are also used for its carapace and plastron. A few sacks of the plastron, along with the sun-dried plastron are found inside a warehouse. We also found the turtle carapace and plastron from freshly slaughtered turtle being dried in the sun (Figure 1C and D). Different from Sampit, we did not find the use of turtle meat for local consumption in Palembang. Nevertheless, we still found dead C. amboinensis and S. crassicollis. The inadequate stored facilities for turtle caused a high rate of mortality. The dead turtles in pools were harvested for its carapaces and plastrons (Figure $1 \mathrm{E}$ and $\mathrm{F}$ ).

The finding that local communities around the Sampit consume of turtle's meat becomes an important concern. There has never been a report on the demand market for turtle meat in Indonesia. Although the turtle demand market poorly reported, it should be regulated as a strategy for domestic utilization does not exceed the annual quota. Domestic quota is allocated from $10 \%$ of the nationally total harvested allowance. For example, if the national harvest quota of C. amboinensis is 13,200 per year, then the export quota is allowed in level 12,000, and 1,200 is allocated for domestic commercial use. Unfortunately, domestic utilization is rarely recorded. The inspection of companies who has harvest permit in the region level becomes a vital concern by the government, considering the increase of national utilization. If there is a local consumption market must be reported and monitored.

So far, the meat market for consumption in In- donesia has never been known. We assumed that also possible that the slaughtering activity is a motive for obtaining carapace and plastron. The high price is likely to become a reason for harvesting carapace and plastron. Given carapace and plastron are the basic ingredients used for Traditional Chinese Medicine (TCM) [17]. Turtle shells of $C$. amboinensis and $S$. crassicollis have long been used for the TCM ingredients. It is still unclear whether turtle meat and carapace can significantly cure various diseases, as TCM claimed. But the perception of Chinese people believed in the efficacy of hard-shell turtle for TCM, so the interest in using it's for medicine is high. According to ancient Chinese believe that the tortoise has the property to restore muscle spasms due to overtraining, replenish vital organs, treat fever, and liver [29]. A study reported that some species, such as $C$. trifasciata could reduce cancer and other diseases [30]. Researchers in their study evaluated the content of meat and turtle shells [29]. The value of fatty acids from turtle meat is lower than crab and shellfish [31]. The amino acid score (AAS) of the turtle shell is less than 100, which means low nutritional content. AAS is widely used as a parameter for evaluating the nutritional quality of proteins [32]. The calcium and phosphorus content in the $C$. trifasciata shell is greater than Mauremys mutica [29]. The selenium content in turtle shells is used as a claim to promote the use of turtle products such as TCM [30]. Although there is evidence that selenium can reduce the incidence of a tumor. Selenium deficiency often associated with heart disease, impaired immune function, and the development of several viruses. The selenium content in C. trifasciata, C. mouhotii, $M$. sensensis, $M$. mutica and Geoemyda spengeleri $(0.58 \mu \mathrm{g} / \mathrm{g}$ dry weight (DW)) is higher than Mauremys reevesii $(0.15 \mu \mathrm{g} / \mathrm{g}$ DW). Close relatives of C.trifasciata as a sister species of $C$. amboinensis had a selenium content that showed a high rate of $3.18 \mu \mathrm{g} / \mathrm{g}$ DW. Nevertheless, the selenium content in C.trifasciata was high but still lower than the softshell turtle which $5.4 \mu \mathrm{g} / \mathrm{g}$ DW. The results of this study proved that the claim of selenium content in hardshell turtle especially ( $M$. reevesii and $C$. trifasciata) for treatment with TCM is not enough.

\section{Trade network}

Turtle trade network in Sampit involves few areas around the middleman. Six collectors are re- 
Table 1. Catching the number of turtles in Sampit City obtained from the interviews with the middleman

\begin{tabular}{ccccc}
\hline No & Supplier & Hunting Location & Catching Number & Frequency of Turtle Shiping to middleman \\
\hline 1. & A & Kuala Pembuang & $200 \mathrm{~kg}$ & once a week \\
2. & B & Kuala Pembuang & $450-1,000 \mathrm{~kg}$ & once a week \\
3. & C & Kuala Pembuang & $350 \mathrm{~kg}$ & once a week \\
4. & D & Jemaras & $300 \mathrm{~kg}$ & once a week \\
5. & E & Sembuluh & $200 \mathrm{~kg}$ & once a month \\
6. & F & Katingan & $200 \mathrm{~kg}$ & once a month \\
7. & G & Ogan Komering Ilir & $500 \mathrm{~kg}$ & once a month \\
\hline
\end{tabular}

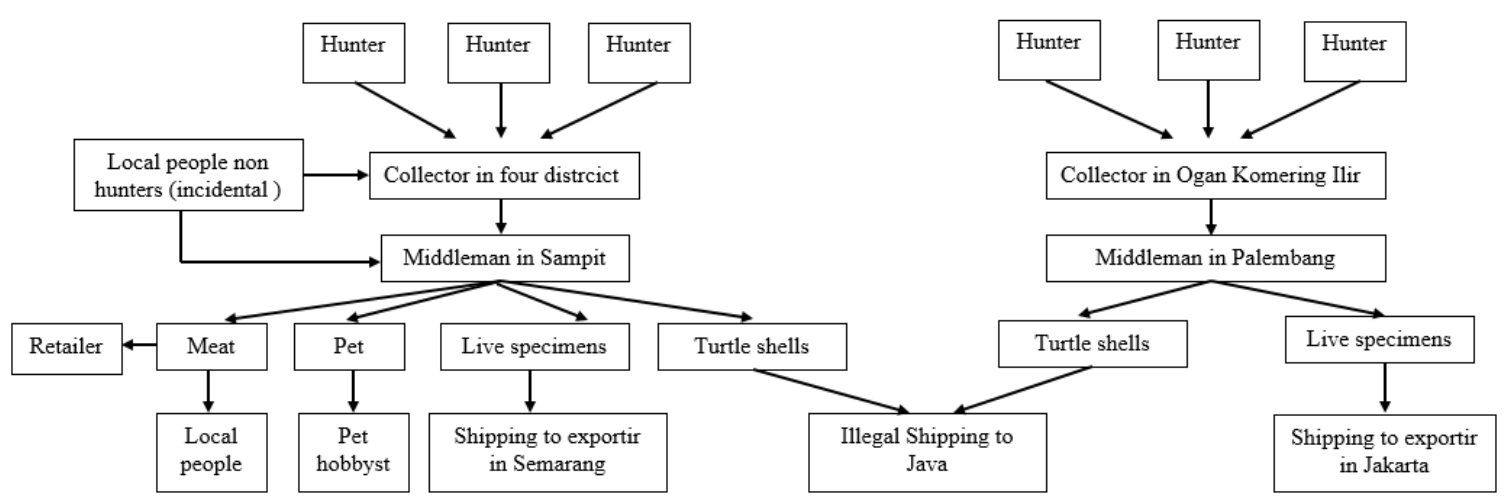

Figure 2. Trading network of turtle trade in Central Borneo and South Sumatra

corded from four regencies (Kuala Pembuang, Jemaras, Katingan, and Sembuluh). Each supplier gets a supply of turtles from hunters who catch and sell them routinely. Besides selling to the supplier, few hunters from Kuala Pembuang also send turtles directly to the middleman (Table 1). This may be the reason why the largest turtle supply enters middleman in Sampit is from Kuala Pembuang. Other than the hunters, residents in Sampit also incidentally supply the turtles for the middleman (Figure 2). Most non-hunters have other jobs, so they only do this for addition of their income.

The hunters caught turtles using bamboo-fishtraps which set in the potential habitat of turtles. Periodically, the trap is being checked to monitor. C. amboinensis and S. crassicollis collected are then sold to the supplier or middleman with a price of $0.91 \mathrm{USD} / \mathrm{kg}$. Catching reptiles and amphibians by trapping is proven to provide a relatively high income for local people [33]. The middleman then sells back the turtles to the consumer, as described in Figure 2 (domestic market). Here we can conclude that the middleman plays an important role in the turtle network. Based on interviews with three non-hunters who conducted transactions in
Sampit, they are people who live in the oil palm plantations area. They did not set a trap to harvest turtles, but they only caught turtles that found on the edge of a palm plantation irrigation.

In this study, perhaps the abundant population in the wild is the reason for rural people to harvest. Even though harvesting communities do not have the legality to collect [34]. But they still carry out these activities because of economic emphasis. [35] revealed that three variables caused illegal trade in the skin of Python reticulatus, including poverty, abundant population, and quota. The hunters in rural areas do not know about harvest quotas, regulations, and management harvesting. They only carried out wildlife hunting to get the money for their lives. The proceeds of the funds are used to fulfill their families such as food and other expenses [36]. So, a good strategy must be created so that a conservation goal can be achieved by not giving adverse effects to the people who depend their life on wildlife.

In Sampit, the carapace and plastron were not sent to the importer country directly, but shipping to Java via a port in South Borneo. However, the trading network of the carapaces and plastrons 
from Palembang cannot be ascertained whether headed straight to a large illegal carapace and plastron trade in Java, to another network trade, or even direct shipping. This indicates an illegal route of carapace trade in Indonesia. Further investigation is needed to uncover this carapace and plastron trade network.

\section{Harvest quota and management}

Recently, MA CITES of Indonesia sets 12,000 individuals as the number of amboina turtles exported to worldwide annually. Each province has the limit numbers of catching the turtles. Central Borneo Province has the number of catching turtles for 1,000 individuals as the living one (consumption) and 700 individuals as pets. Meanwhile, South Sumatra Province has 500 individuals' turtles for consumption and 1,500 individuals as pets (No. 441/KSDAE/SET/KSA.2/12/ 2018). According to the national rules of wild plants and animals harvesting in 2019, 2700 individuals is the total maximum number of $S$. crassicollis for the export purpose which South Sumatra has a quota of its species at 500 individuals. On the other hand, Central Borneo does not have any local quota to harvest this species. On the opposite, more than 1,000 kilograms of turtles are found entering Sampit middleman. According to the number of harvests from both locations that turtles catching at the two locations indicated over quota and the illegal trade of $S$. crassicollis in Sampit is occurred. Even though the domestic quota of turtle's consumption is available, the number of turtles catching exceeds the annual quota at the province level.

C. amboinensis is included in Appendix II CITES. Thus, the system of its trade is regulated through the quota system and monitored by parties' countries (Article IV CITES) [37]. At this time, Indonesia gets a Review of Significant Trade for $C$. amboinensis as the effect of the high trade volume in 2011 - 2015. Another reason is the exporting of 20,000 kg carapaces to China [38]. The Scientific Authority (SA) CITES of Indonesia has recommended to band the carapace trade since 2016 because the traceability of turtle number cannot be justified and potentially can drive to the overexploitation

The management of wildlife trade in Indonesia is regulated in several regulations. Indonesia has several regulations, such as Act No. 5 of 1990 and Government Regulation No. 8 of 1999 which re- gulates the Conservation of Biological Resources and their Ecosystems and the Utilization of Wild Plants and Animals (TSL). The issue of administration of the capture and trade of TSL in Indonesia which regulates in the decree of the Minister of Forestry SK 447 of 2003. However, the finding of illegal trade in turtle from this study indicates that the level of implementation in the monitoring of wild harvest specimens still needed to improve.

As mentioned in a decree of the Minister of Forestry SK 447 of 2003, all TSL capture activities in Indonesia for commercial and non-commercial purposes for domestic and export must be accompanied by the permit issued by the Directorate of KSDAE. In the aspect of controlling the trade of TSL, Indonesia imposes a regulation that every flow of wildlife must be accompanied by SATSDN documents for domestic, commercial, and SATS-LN for export commercial. Company must obey these rules as evidence that the activities carried out are legal. From these documents, the circulation of TSL in Indonesia can be monitored. As law enforcement of the TSL trade regulation, the companies that have capture permits violate the provisions such as the number of catches, the documents transport, capture without licenses, and the trade of animals that listed in Appendix I CITES, the company get the penalty from the Management Authority as a consequence of its.

An aspect that weakness in TSL trading activities in Indonesia is the supervision of harvesting. The violation of harvest quota has been reported. [1] monitored in Sumatra and Borneo show the trade of three reptile species: Gekko gecko, Acrochordus javanicus, and Amyda cartilaginea which exceeded the specified quota. This condition occurred that harvest supervision practices in the regions are lacking. The Directorate of Natural Resource Conservation must carry out of harvest inspection in hunters and middleman as the initial step to control and implement the quota regulations. So, if there is an excess of the quota, it can be stopped and it is prohibited to harvest more than the quota obtained by each company.

The aspect of natural resource utilization in Indonesia is contained in Government Regulation $\mathrm{P}$ No. 8 of 1999. The natural resources can be used for the prosperity of the communities. In these regulations, the intended utilization aspects are divided into research; development, captivity, hunting, trade, demonstration, exchange, cultivation, 
and pet. It should be noted that utilization must pay attention to the Sustainability of wild plants and animals. But, the communities around the forest sold the wild plants and animals for benefit and most of them ignore of conservation aspects. They must be given of knowledge about the importance of conservation and efforts to reduce dependence on wildlife by managing in the tourism sector [39]. Tourism development by utilizing turtles as tourist attractions can be an alternative to improve the economic aspects of communities. The abundant potential of turtles can be used as an educational tool for tourist visitors. The challenge of turtle conservation is the change of livelihood communities from being a turtle hunter to a conservationist requires a big effort and takes a long time. Finally, we hoped that the utilization of turtles applying the conservation aspects.

\section{Conclusion}

Through places monitored, it is clear that the harvesting of $C$. amboinensis and S. crassicollis is not following the quota established by the government. Instead of following the CITES regulation, the middlemen tend to look for more profit through illegal trade. Our essential note is about the use of carapace and plastron in large quantities that can drive to overexploitation that have an impact on the declining wild population.

\section{Acknowledgment}

Researchers thank all respondents who were involved in the trade data collection. We also thank KKH (the Directorate of Biodiversity Conservation), who facilitated the survey activity in Sampit and also gave facilities to collect the data. This research is funded by project DIPA Pusat Penelitian Biologi LIPI 2019 "Studi dan Monitoring Tumbuhan dan Satwa Liar yang Masuk Apendiks CITES Serta Aspek Ekonomi dan Antropologinya (34000.002.051 A). All authors have equally contributed to the paper.

\section{References}

1. Nijman V, Shepherd CR, Mumpuni, Sanders KL (2012) Over-exploitation and illegal trade of reptiles in Indonesia. Herpetological Journal 22:83-89

2. Lenzen M, Moran D, Kanemoto K (2012) International trade drives biodiversity threats in developing nations. Nature 486:109-112.

3. Weinbaum KZ, Brasheres JS, Golden CD, Getz WM (2013) Searching for sustainability:are assessments of wildlife harvest behind the times. Ecology Letter 16:99111. doi: 10.1111/ele.12008

4. Brashares JS, Golden CD, Weinbaum KZ et al. (2011) Economic and Geographic drivers of wildlife consumption in rural Africa. Proceeding National Academy Science 108 (32): 13931-13936. doi: 10.1073/pnas.1011526108

5. Golden CD, Fernald LCH, Brasheres JS et al. (2011) Benefits of wildlife consumption to child nutrition in a biodiversity hotspot. Proceedings of the National Academy of Sciences 108(49): 19653-19656

6. Luck GW, Harrington R, Harrison PA (2009) Quantifying the contribution of organism to the provision of ecosystem services. Bioscience 59;223-235

7. Milner-Gulland EJ, Bennett EL (2003) Wild meat: the bigger picture. Trends in Ecology and Evolution 18(7): 351-357

8. Nijman V (2010) An overview of international of wildlife trade from Southeast Asia. Biodiversity and Conservation 19(4): 1101-1114

9. Wyler LS, Sheikh PA (2008) International illegal wildlife trade. Library of Congress Washington DC Congressional Research Service. https://apps.dtic.mil/docs/citations/ADA486486. Accessed date: October 2019.

10. Luiselli L, Staruita, Carpaneto GM et al. (2016) A short review of the international trade of wild tortoises and Freshwater turtle across the world and throughout two decades. Chelonian Conservation and Biology 15(2):167-172. doi : 10.2744/CCB-1216.1

11. Bush ER, Baker SE, Macdonald DW (2014) Global trade in exotic species pets 2006-2012. Conservation Biology 28: 663-676.

12. Buhlmann KA, Akre TSB, Iverson JB et al. (2009) A global analysis of tortoises and freshwater turtle distributions with identification of priority conservation areas. Chelonian conservation and Bioloogy8:116-149 doi.org/10.2744/CCB-0774.1.

13. van Dijk PP, Stuart BL, Rhodin AGJ (2000) Asian Turtle trade. Chelonian Research Monographs 2.

14. Stuart BL, Thorbjarnarson J (2003) Biological prioritization of Asian Countries for Turtle Conservation. Chelonian Conservation and Biology 4(3): 642-647.

15. Shi-Ping G, Chow AT, Fong JJ (2009) The Chelonian Trade in the Largest pet market in China: scale, scope and impact on the turtle conservation. Oryx 43 (02): 213-216.

16. Chen TH, Chang HC, Lue KY (2009) Unregulated trade in turtle shells for Chinese traditional Medicine in East and Southeast Asia: The case of Taiwan.Chelonian Conservation and Biology 8 (1):11-18. doi: 10.2744/CCB0747.1

17. Schoppe, S (2009) Status, trade dynamics, and management of the Southeast Asian Box Turtle in Indonesia. TRAFFIC Southeast Asia, Petaling Jaya, Malaysia. 105.

18. Riyanto A, Mumpuni (2018) Populasi dan karakteristik kura-kura (Cuora amboinensis \& Siebenrockiella crassicollis) yang dipanen di Jambi dan Sumatera, Indonesia. Proceeding Seminar Nasional Konservasi dan Pemanfaatan Tumbuhan dan Satwa Liar"Riset Sebagai Fondasi Konservasi dan Pemanfaatan Tumbuhan dan Satwa Liar; 17-26. Bogor Indonesia November 2018.

19. Broad S, Mulliken T, Roe D (2003) The trade in wildlife. Earthscan. UK 
20. Ernst CH, Barbour RW (1989) Turtles of the world. Smithsonian. Washington.

21. Iskandar D.T (2000) Turtles and crocodiles of Insular Southeast Asia and New Guinea. PAL Media. Bandung

22. Alex (2008) The first black marsh turtle to hatch in a European zoo. www.bristolzoo.org.uk. Accessed date January 2020.

23. Jenkins M (1995) Tortoises and freshwater turtles: the trade in South East Asia. TRAFFIC International, Cambridge (UK). 1-49 pp

24. Whitaker R, Andrews HV (1997) Captive breeding of Indian turtles and tortoises at the Centre for Herpetology/Madras Crocodile Bank. In: van Abbema, J. (Ed.). Proceedings: Conservation, restoration and management of tortoises and turtles: An international conference, July 1993, State University of New York. New York Turtle and Tortoise Society, New York. 166-170.

25. Ji-Chao W, Ping S, Hai-tao S et al. (2011) Reproduction and nesting of the Endangered Keeled Box Turtle (Cuora mouhotii) on Hainan Island, China. Chelonian Conservation and Biology 10(2): 159-164

26. Franklin CJ. 2007. Turtles: an extraordinary natural history 245 million years in the making. Voyageur. China

27. Ferlito C, Respatiardi H (2018) Policy reforms on poultry industry in Indonesia. Discussion paper, center for Indonesian policy studies (CIPS) Jakarta. www. enconstor.eu. Accessed date on January 2020

28. Sandalj M, Treydte AC, Ziegler S (2016) Is wild meat luxury? Quantifying wild meat demand and availability in Hue, Vietnam. Biological Conservation 194: 105112 doi: 10.1016/j.biocon.2015.12.018

29. Meiling H, Haitao S, Lirong F et al. (2008) Scientific refutation of Traditional Chinese Medicine claims about turtles. Applied Herpetology 5:173-187

30. Li G, Tang D, Fang K (2000) An analysis of amino acids in the meat of Cuora trifasciata. J. Zool. 19: 165-166
31. Chen DW, Zhang M, Shrestha S (2006) Compositional characteristics and nutritional quality of Chinese mitten crab (Eriocheir sinensis). Food Chem 103: 1343-1349

32. Iqbal A, Khalil LA, Ateeq N, Khan MS (2006) Nutritional quality of important food legumes. Food Chem 97: 331-335

33. Robinson JE, Griffiths RA, Fraser IM et al. (2018) Supplying the wildlife trade as livelihood strategy in a biodiversity hotspot. Ecology and Society 23(1):13

34. Robinson JE (2016) Supplying the exotic pet trade: conservation and livelihood implications. Dissertation. University of Kent. UK

35. Natusch DJD, Lyons JA, Mumpuni et al. (2016) Sustainable management of the trade in Reticulated Python skins in Indonesia and Malaysia. A report under the 'Python Conservation Partnership’ programme of research. Occasional Paper of the IUCN Species Survival Commision No.61. IUCN. Switzerland.

36. Nossal K, Natusch DJD, Khadiejah S et al. (2016) People and trade: the livelihood impacts of python skin trade in Peninsular Malaysia. International Trade Centre.

37. CITES (2019) Article IV CITES. www.cites.org. Accessed date: November 2019.

38. UNEP-WCMC (2018) Report on species/country combinations selected for review by the animal committee following CoP17. UNEP World Conservation Monitoring Centre, Cambridge. UK. http://sea-bov.unepwcmc.org/citestrade. Accessed date: March 2019

39. Hunt CA, Vargas E (2018) Turtles, Ticos, and Tourist; protected areas and marine turtles conservation in Costa Rica. Journal of Park and Recreation Administration 36: 101-11 
